International Business and Global Economy 2017, no. 36, pp. 209-221

Biznes międzynarodowy w gospodarce globalnej 2017, nr 36, s. 209-221

Edited by the Institute of International Business, University of Gdańsk

ISSN 2300-6102

e-ISSN 2353-9496

DOI 10.4467/23539496IB.17.014.7462

Marcin Soniewicki

Uniwersytet Ekonomiczny w Poznaniu

\title{
Market orientation and competitiveness of Polish manufacturing companies
}

The paper examines different kinds of manufacturing companies with various levels of market orientation. Its main aim is to test whether their level of competitiveness is correlated with their level of market orientation. The paper is based on a quantitative research in which 334 manufacturing companies were examined. For measuring market orientation, the MKTOR scale developed by Narver and Slater was used. The competitive position of the analysed firms was determined using the Competitiveness Index developed by Fonfara. The statistical significance of the observed differences was tested using the Mann-Whitney U-test. The study shows that in every type of manufacturing companies, their competitiveness grows along with increasing market orientation. However, the extent of this growth differs depending on company type. The results also show that it is always beneficial to increase market orientation, as the firms with the highest market orientation belong to the most competitive $5 \%$ of manufacturing companies.

Keywords: market orientation, marketing, competitiveness, competitive advantage, manufacturing

JEL classification: D20, L60, M11, M20, M31

\section{Orientacja rynkowa a konkurencyjność polskich przedsiębiorstw}

W artykule przeprowadzono analizę licznych przedsiębiorstw produkcyjnych charakteryzujących się różnymi poziomami orientacji rynkowej. Głównym celem publikacji jest zbadanie, czy poziom konkurencyjności firm produkcyjnych jest związany z poziomem ich orientacji rynkowej. W artykule wykorzystano wyniki badania ilościowego przeprowadzonego wśród 334 przedsiębiorstw produkcyjnych. W celu dokonania pomiaru poziomu orientacji rynkowej zastosowano skalę MKTOR stworzoną przez Narvera i Slatera. Pozycję konkurencyjną badanych firm sprawdzono za pomocą Indeksu Konkurencyjności stworzonego przez Fonfarę. Istotność statystyczna zaobserwowanych różnic została sprawdzona za pomocą testu U Manna-Whitneya. Wyniki pokazują, że w każdym rodzaju firm produkcyjnych konkurencyjność rośnie wraz ze wzrostem poziomu orientacji rynkowej. Niemniej skala wzrostu różni się w zależności od typu podmiotu. Rezultaty pokazują również, że zawsze opłaca się zwiększać poziom orientacji rynkowej, gdyż przedsiębiorstwa z najwyższym poziomem orientacji rynkowej należą do 5\% najbardziej konkurencyjnych firm produkcyjnych.

Słowa kluczowe: orientacja rynkowa, marketing, konkurencyjność, przewaga konkurencyjna, produkcja

Klasyfikacja JEL: D20, L60, M11, M20, M31 


\section{Introduction}

Competing in today's rapidly changing market is becoming more and more difficult for companies. Some of the reasons include globalisation and competition from low-cost countries. A question thus arises as to how companies from medium and highly developed countries should build their competitive advantage. In recent years, many business practitioners and scientists had one answer to this question - innovation. Nevertheless, innovation means more than simply improving a process or a product. This improvement should be useful and accepted by the market. This simple yet problematic issue is sometimes being forgotten, which is why many innovations do not contribute to increasing the competitive position of the businesses that introduce them. What may actually help in these circumstances? This article suggests at least a partial answer - a well-known, sometimes treated as obvious and, in fact, neglected concept: market orientation. The article's main aim is therefore to test whether manufacturing companies' level of competitiveness is correlated with their level of market orientation.

\section{Literature review}

The literature describes the orientation of an enterprise as its manner of functioning [Noble, Sinha, Kumar, 2002, p. 25; Pazio, 2007, p. 14]. Companies of the past concentrated more on their internal operations, but when the demand for their offer started to decline, they gradually adopted a more externalised orientation. Over time, a discernible trend emerged, as particular orientations started to gain popularity: production orientation, product orientation, followed by sales orientation and marketing (or customer) orientation [Niestrój, 2003; Pazio, 2007; Fonfara, 2014; Soniewicki, 2015]. The latter is the most common among contemporary businesses [Fonfara, 2014; Soniewicki, 2015].

Tajeddini, Trueman, and Larsen [2006] emphasise that the essence of marketing is to perceive the enterprise from the customer's perspective. Marketing places particular significance on satisfying customer needs [Armstrong, Kotler, 2011; Kaźmierczyk, 2011, p. 22]. In general, it concentrates on putting customer and his needs at the centre of the firm's interests. This, however, although important, is not sufficient to achieve competitive advantage - firms should also pay attention to other kinds of entities on the market [Fonfara, 2014]. This is one of the reasons why a more complex orientation - market orientation - has been put forward.

The concept of market orientation became well known in the literature probably with the release of Shapiro's 1988 article, which explained it with the example 
of a company located in Indiana, US. In his opinion, three issues are of prime importance to every company: understanding how customers use their products, ensuring smooth cooperation between all departments and, finally, observing their key competitors. Successfully performing these tasks is supposed to help the company to first identify and then take advantage of market opportunities. Shapiro notes, however, that the former does not guarantee the latter. He believes that only undertaking all three described actions may prevent a company from missing, or not benefiting from, market opportunities. Apart from Shapiro's valuable contribution, the two most often cited articles on this topic, based on data from Google Scholar, are the classic papers by Narver and Slater [1990] and by Kohli and Jaworski [1990].

All of the presented papers assign a unique value to the issue of market orientation, but while the ones written by Shapiro as well as Kohli and Jaworski are rather theoretical, Narver and Slater pay particular attention to the company's competitors, both present and future, whose moves should be constantly analysed, and highlight the often problematic issue of interdepartmental cooperation, which makes their paper more practical and useful in research practice [Soniewicki, 2015].

This article defines market orientation, according to the perspective of Narver and Slater, as a three-component construct that includes customer orientation, competitor orientation, and inter-functional coordination. Although the importance of market orientation has already been proved for other types of companies and in different conditions, it has never been the subject of analysis among Polish manufacturing firms. This article attempts to fill this research gap.

\section{Conceptual model}

The situation of manufacturing companies in medium and highly developed countries seems quite difficult. One of the reasons is the widespread phenomenon of offshoring. In Europe and, to some extent, the US there are also powerful unions and regulations [Loch, Chick, Huchzermeier, 2007]. Nevertheless, it must be underlined that manufacturing is a very important sector that generates jobs and wealth in industrialised economies [Jovane et al., 2008], which makes its analysis especially important and interesting. A question thus arises as to how companies from these countries can compete in the current globalised market. One thing is certain - they need to change. In the survey conducted by the Economist Intelligence Unit [2011], 90\% of executives of American manufacturing companies stated that they consider innovation as an important or extremely important factor for achieving long-term success. 
In order to properly implement innovation processes, however, market orientation is of key importance. High level of market orientation helps companies to adapt to the constantly and rapidly changing customer tastes and provides them with crucial market knowledge necessary to keep up with the trends by creating and appropriately refreshing their market offer. The main aim of this article is therefore to test whether the competitiveness level of manufacturing companies is correlated with their level of market orientation. It adopts the definition of the competitiveness level proposed by Fonfara [2007], which views it as the competitive position of a firm with respect to its closest competitors, and which will be described in more detail in the next section.

The relation between the market orientation and the performance of companies has already been studied in the literature [e.g. Harris, 2001]. Nevertheless, enterprises differ in their characteristics and processes, which is why this article concentrates specifically on manufacturing companies. Moreover, since they also do not constitute a monolith, in order to get more detailed results they have been divided into smaller groups according to their size and level of product technology. The former criterion has already been used to examine small and mediumsized manufacturing businesses in the US [Pelham, 2000] and India [Gaur, Vasudevan, Gaur, 2011] - this article, however, also takes into account large companies, which were not covered in some studies. Furthermore, the previous market orientation and competitiveness analyses did not distinguish companies according to the level of product technology. This is a very important criterion, as manufacturing companies in the same technology groups are often similar and frequently compete with each other. The unique value of the present study also stems from the fact that it has been conducted in a country where market orientation is rather rarely analysed-Poland. It is a medium developed country, in which it is becoming more and more difficult to achieve cost advantage and manufacturing companies need to search for new ways of increasing their competitiveness. The concept of market orientation might be one of the essential tools in this process.

\section{Methodology}

This article is based on the results of a quantitative research conducted among companies operating in Poland in 2012 and at the beginning of 2013. The data was obtained through a questionnaire delivered to the respondents in one of two ways. The first way was an electronic surveying system created by the author using his experience from previous quantitative studies with some assistance from a computer scientist. The idea was to optimise the surveying process and receive as many filled-in questionnaires as possible. The system was sending customised 
links to each respondent and automatically delivering reminders to those who did not fill in the survey. The questionnaire was also prepared in a traditional paper form and sent by post to those companies whose e-mail addresses were not available. The sampling frame was the Kompass Poland database. In the end, more than 1,200 filled-in questionnaires were obtained. Of interest in this paper is, however, only the subsample of 334 manufacturing companies.

Table 1. The number of companies in the examined sample (by size)

\begin{tabular}{|l|c|}
\hline \multicolumn{1}{|c|}{ Size } & No. \\
\hline Micro-enterprises & 58 \\
\hline Small enterprises & 134 \\
\hline Medium-sized enterprises & 108 \\
\hline Large enterprises & 34 \\
\hline Total & $\mathbf{3 3 4}$ \\
\hline
\end{tabular}

Source: Own elaboration.

Most of the firms in the sample are small (10-49 employees) and mediumsized enterprises (50-249 employees). There is also a substantial number of microenterprises (less than 10 employees). The smallest group are large enterprises (more than 250 employees). Since the manufacturing industry consists of various entities that differ in many ways, in order to thoroughly analyse them it was necessary to introduce another criterion. The OECD proposed a very useful division of manufacturing companies into low, medium-low, medium-high, and high technology companies according to the technology level of the goods they produce [Hatzichronoglou, 1997]. In order to simplify the questionnaire, the research distinguished only three groups: 1 - low and medium-low technology, 2 - medium-high technology, and 3 - high technology.

Table 2. The number of companies in the examined sample (by type)

\begin{tabular}{|l|r|}
\hline \multicolumn{1}{|c|}{ Type } & No. \\
\hline Low and medium-low technology & 180 \\
\hline Medium-high technology & 115 \\
\hline High technology & 39 \\
\hline Total & $\mathbf{3 3 4}$ \\
\hline
\end{tabular}

Source: Own elaboration.

The largest group in the sample consists of low and medium-low technology manufacturing companies. The number of medium-high technology firms, al- 
though still significant, is much lower. High technology enterprises constitute the smallest group in the sample.

The main area of interest for the article is market orientation. The literature offers many methods of measuring market orientation. This article uses the MKTOR scale developed by Narver and Slater [1990]. It consists of fourteen questions divided into three groups - customer orientation (six questions), competitor orientation, and interfunctional coordination (four questions each). A 5-point Likert scale was used for all questions; the grade of 1 meant the lowest level of particular factor and the grade of 5 - the highest. The MKTOR scale was used for several reasons. Farrell and Oczkowski [1997, pp. 6-7] used both well-known market orientation scales - MARKOR and MKTOR - in Australia and, upon observing how poorly they performed, concluded that they do not fit into the country's 'business culture'. Consequently, the fact that the MKTOR scale was already tested in Poland in a study performed by Hooley et al. [2000] is its important advantage. Some authors also claim that the MARKOR scale measures the level of marketing orientation, not market orientation [Wrenn, 1997, p. 33; Hooley et al., 2000, p. 274]. Last but not least, the MKTOR scale was chosen for its higher statistical reliability as compared to the MARKOR scale [Pelham, Wilson, 1996, p. 33].

The competitiveness level of the examined companies, i.e., their competitive position with respect to their closest competitors, was measured using the Competitiveness Index developed by Fonfara [2007], which takes into account four financial and non-financial elements: profit, market share, return on investment, and value of sales. The respondents assessed their companies in the mentioned areas on a 5-point Likert scale as occupying a: 1 - much worse, 2 - worse, 3 - more or less the same, 4 - better, or 5 - much better position than their closest competitors. The final value is the arithmetical average of the four results.

The Mann-Whitney U-test was applied using the IBM SPSS software (Statistical Package for Social Sciences) in order to test the statistical differences between particular results.

\section{Research results}

The first analysis concentrates on the market orientation and competitiveness level of all the examined manufacturing companies.

Table 3 shows that the competitive position of manufacturing companies with an average or lower than average $(\leq 3)$ level of market orientation is worse than their closest competitors (2.52). Nevertheless, such companies constitute only $15 \%$ of the sample. Firms with market orientation higher than average $(>3)$ have 
a much higher competitiveness level (3.22). The difference amounts to 0.70 and therefore is statistically significant.

Table 3. Market orientation and competitiveness of manufacturing companies

\begin{tabular}{|c|c|c|c|c|c|}
\hline $\begin{array}{c}\text { Market } \\
\text { orientation }\end{array}$ & $\begin{array}{c}\text { Competi- } \\
\text { tiveness } \\
\text { Index }\end{array}$ & Difference & $\begin{array}{c}\text { p-value of } \\
\text { Mann-Whitney } \\
\text { U-test }\end{array}$ & $\begin{array}{c}\text { No. of } \\
\text { companies }\end{array}$ & $\begin{array}{c}\text { Share } \\
(\%)\end{array}$ \\
\hline$\leq 3.0$ & 2.52 & - & - & 49 & 15 \\
\hline$>3.0$ & 3.22 & $0.70^{* * *}$ & $<0.001$ & 285 & 85 \\
\hline$>3.5$ & 3.38 & $0.85^{* * *}$ & $<0.001$ & 188 & 56 \\
\hline$>4.0$ & 3.57 & $1.05^{* * *}$ & $<0.001$ & 76 & 23 \\
\hline$>4.5$ & 4.01 & $1.49^{* * *}$ & $<0.001$ & 17 & 5 \\
\hline
\end{tabular}

Notes: ${ }^{* * *} \mathrm{p}<0.01$.

Source: Own elaboration.

A closer analysis of the above results reveals that the increasing level of market orientation is accompanied by an even more dynamic increase in the competitiveness of manufacturing companies: $\mathrm{MO}>3.5-\mathrm{CI}=0.15 ; \mathrm{MO}>4-\mathrm{CI}=0.20$; $\mathrm{MO}>4.5-\mathrm{CI}=0.44$. The latter result is especially interesting. Manufacturing firms with ultra-high market orientation $(>4.5)$ are characterised by much higher competitiveness than their closest competitors (4.01). There are only a few such companies - they constitute the top 5\% of the surveyed companies.

The above analysis allows to draw important conclusions. It is, however, relatively general, as it considers all kinds of manufacturing companies. In order to learn more about the importance of market orientation, a more detailed analyses are presented below, which concentrate on specific technology (Tables 4-6) and size groups (Tables 7-10).

Table 4. Market orientation and competitiveness of low and medium-low technology manufacturing companies

\begin{tabular}{|c|c|c|c|c|c|}
\hline $\begin{array}{c}\text { Market } \\
\text { orientation }\end{array}$ & $\begin{array}{c}\text { Competi- } \\
\text { tiveness } \\
\text { Index }\end{array}$ & Difference & $\begin{array}{c}\text { p-value of } \\
\text { Mann-Whitney } \\
\text { U-test }\end{array}$ & $\begin{array}{c}\text { No. of } \\
\text { companies }\end{array}$ & $\begin{array}{c}\text { Share } \\
(\%)\end{array}$ \\
\hline$\leq 3.0$ & 2.38 & - & - & 30 & 17 \\
\hline$>3.0$ & 3.23 & $0.85^{* * *}$ & $<0.001$ & 150 & 83 \\
\hline$>3.5$ & 3.38 & $1.01^{* * *}$ & $<0.001$ & 99 & 55 \\
\hline$>4.0$ & 3.65 & $1.27^{* * *}$ & $<0.001$ & 32 & 18 \\
\hline$>4.5$ & 4.09 & $1.72^{* * *}$ & $<0.001$ & 8 & 4 \\
\hline
\end{tabular}

Notes: ${ }^{* *} \mathrm{p}<0.01$.

Source: Own elaboration. 
Table 4, which focuses on low and medium-low technology manufacturing companies, shows that the difference between the competitiveness level of companies with an average or lower than average $(\leq 3)$ and higher than average $(>3)$ level of market orientation is greater than in the entire sample ( 0.85 in comparison to 0.70 ) and statistically significant. Of importance is the fact that the firms with an average or lower than average $(\leq 3)$ level of market orientation are characterised by very low competitiveness (2.38). It should also be noted that there are fewer entities with the highest levels of market orientation $(>4$ and $>4.5)$ in this group than in the entire sample, but their market orientation levels are higher (3.65 and 4.09, respectively). This indicates that market orientation constitutes a very important factor in the competitiveness of these enterprises.

Table 5. Market orientation and competitiveness of medium-high technology manufacturing companies

\begin{tabular}{|c|c|c|c|c|c|}
\hline $\begin{array}{c}\text { Market } \\
\text { orientation }\end{array}$ & $\begin{array}{c}\text { Competi- } \\
\text { tiveness } \\
\text { Index }\end{array}$ & Difference & $\begin{array}{c}\text { p-value of } \\
\text { Mann-Whitney } \\
\text { U-test }\end{array}$ & $\begin{array}{c}\text { No. of } \\
\text { companies }\end{array}$ & $\begin{array}{c}\text { Share } \\
(\%)\end{array}$ \\
\hline$\leq 3.0$ & 2.77 & - & - & 12 & 10 \\
\hline$>3.0$ & 3.12 & 0.35 & 0.118 & 103 & 90 \\
\hline$>3.5$ & 3.30 & $0.53^{* *}$ & 0.042 & 65 & 57 \\
\hline$>4.0$ & 3.46 & $0.69^{* *}$ & 0.020 & 34 & 30 \\
\hline$>4.5$ & 3.85 & 1.08 & 0.104 & 5 & 4 \\
\hline
\end{tabular}

Notes: ** $\mathrm{p}<0.05$.

Source: Own elaboration.

Table 5, which concentrates on medium-high technology manufacturing companies, shows that $90 \%$ of them are characterised by higher than average $(>3)$ market orientation. The difference between the competitiveness of the firms with average or lower than average $(\leq 3)$ and higher than average $(>3)$ market orientation is relatively small $(0.35)$ and not statistically significant. Their competitiveness also increases along with market orientation, but not all differences are statistically significant. Market orientation is therefore still important for medium-high technology manufacturing companies but it seems to contribute to their competitiveness to a lesser extent than in the case of low and medium-low technology companies.

Table 6 presents the results for the most advanced type of manufacturing companies - high technology enterprises. In this case competitiveness also increases along with market orientation. The differences are slightly less significant than for low and medium-low technology companies, but much greater than for medium-high technology companies. It should be noted that with each level of market orientation their competitiveness increase accelerates. This group also has 
the largest share $(10 \%)$ of businesses with ultra-high level $(>4.5)$ of market orientation. It must be underlined, however, that it includes much less companies than the previously analysed groups, which results in a lower statistical significance of the observed differences.

Table 6. Market orientation and competitiveness of high technology manufacturing companies

\begin{tabular}{|c|c|c|c|c|c|}
\hline $\begin{array}{c}\text { Market } \\
\text { orientation }\end{array}$ & $\begin{array}{c}\text { Competi- } \\
\text { tiveness } \\
\text { Index }\end{array}$ & Difference & $\begin{array}{c}\text { p-value of } \\
\text { Mann-Whitney } \\
\text { U-test }\end{array}$ & $\begin{array}{c}\text { No. of } \\
\text { companies }\end{array}$ & $\begin{array}{c}\text { Share } \\
(\%)\end{array}$ \\
\hline$\leq 3.0$ & 2.71 & - & - & 7 & 18 \\
\hline$>3.0$ & 3.48 & $0.77^{*}$ & 0.058 & 32 & 82 \\
\hline$>3.5$ & 3.55 & $0.84^{* *}$ & 0.043 & 24 & 62 \\
\hline$>4.0$ & 3.65 & $0.94^{*}$ & 0.055 & 10 & 26 \\
\hline$>4.5$ & 4.06 & $1.35^{*}$ & 0.073 & 4 & 10 \\
\hline
\end{tabular}

Notes: ${ }^{*} \mathrm{p}<0.1 ;{ }^{* *} \mathrm{p}<0.05$.

Source: Own elaboration.

The above results show that manufacturing companies in all technology groups that have an average or lower than average $(\leq 3)$ level of market orientation are less competitive than their closest competitors. It therefore might be risky for them not to invest in market orientation processes to reach at least the average level. Moreover, it is profitable to develop these activities as much as possible.

In order to examine the issue in more depth, Tables 7-10 show the relation between the competitiveness and market orientation in different size groups of manufacturing companies.

Table 7. Market orientation and competitiveness of micro manufacturing companies

\begin{tabular}{|c|c|c|c|c|c|}
\hline $\begin{array}{c}\text { Market } \\
\text { orientation }\end{array}$ & $\begin{array}{c}\text { Competi- } \\
\text { tiveness } \\
\text { Index }\end{array}$ & Difference & $\begin{array}{c}\text { p-value of } \\
\text { Mann-Whitney } \\
\text { U-test }\end{array}$ & $\begin{array}{c}\text { No. of } \\
\text { companies }\end{array}$ & $\begin{array}{c}\text { Share } \\
(\%)\end{array}$ \\
\hline$\leq 3.0$ & 2.38 & - & - & 10 & 17 \\
\hline$>3.0$ & 3.01 & $0.64^{* *}$ & 0.034 & 48 & 83 \\
\hline$>3.5$ & 3.18 & $0.80^{* *}$ & 0.015 & 35 & 60 \\
\hline$>4.0$ & 3.45 & $1.08^{* *}$ & 0.029 & 10 & 17 \\
\hline$>4.5$ & 4.42 & $2.04^{* *}$ & 0.028 & 3 & 5 \\
\hline
\end{tabular}

Notes: ** $\mathrm{p}<0.05$.

Source: Own elaboration. 
Table 7 shows that micro-companies are much less competitive than their closest competitors when their level of market orientation is average or lower than average and similarly competitive when it is above average, but much more competitive when it is very high $(>4)$ and even more when it is ultra-high (4.5). Although all the results are statistically significant, the last one cannot be easily generalised, as there were only three such micro-companies in the sample. It can nonetheless be concluded that an above average $(>3)$ market orientation helps micro-companies to be equally competitive as other firms. In order to be substantially more competitive than their closest competitors they should be characterised by a very high $(>4)$ or ultra-high $(>4.5)$ level of market orientation.

Table 8. Market orientation and competitiveness of small manufacturing companies

\begin{tabular}{|c|c|c|c|c|c|}
\hline $\begin{array}{c}\text { Market } \\
\text { orientation }\end{array}$ & $\begin{array}{c}\text { Competi- } \\
\text { tiveness } \\
\text { Index }\end{array}$ & Difference & $\begin{array}{c}\text { p-value of } \\
\text { Mann-Whitney } \\
\text { U-test }\end{array}$ & $\begin{array}{c}\text { No. of } \\
\text { companies }\end{array}$ & $\begin{array}{c}\text { Share } \\
(\%)\end{array}$ \\
\hline$\leq 3.0$ & 2.31 & - & - & 18 & 13 \\
\hline$>3.0$ & 3.07 & $0.77^{* * *}$ & $<0.001$ & 116 & 87 \\
\hline$>3.5$ & 3.26 & $0.95^{* * *}$ & $<0.001$ & 73 & 54 \\
\hline$>4.0$ & 3.44 & $1.13^{* * *}$ & $<0.001$ & 25 & 19 \\
\hline$>4.5$ & 3.79 & $1.48^{* * *}$ & $<0.001$ & 7 & 5 \\
\hline
\end{tabular}

Notes: ${ }^{* * *} \mathrm{p}<0.01$.

Source: Own elaboration.

Table 8 indicates that market orientation plays a very similar role in the competitiveness of micro- and small companies. The only meaningful difference is that with an ultra-high $(>4.5)$ level of market orientation the former are more competitive than the latter. Nevertheless, it must be underlined that there was only a small number of such firms analysed in the study.

Table 9. Market orientation and competitiveness of medium manufacturing companies

\begin{tabular}{|c|c|c|c|c|c|}
\hline $\begin{array}{c}\text { Market } \\
\text { orientation }\end{array}$ & $\begin{array}{c}\text { Competi- } \\
\text { tiveness } \\
\text { Index }\end{array}$ & Difference & $\begin{array}{c}\text { p-value of } \\
\text { Mann-Whitney } \\
\text { U-test }\end{array}$ & $\begin{array}{c}\text { No. of } \\
\text { companies }\end{array}$ & $\begin{array}{c}\text { Share } \\
(\%)\end{array}$ \\
\hline$\leq 3.0$ & 2.61 & - & - & 16 & 15 \\
\hline$>3.0$ & 3.46 & $0.85^{* * *}$ & $<0.001$ & 92 & 85 \\
\hline$>3.5$ & 3.55 & $0.94^{* * *}$ & $<0.001$ & 62 & 57 \\
\hline$>4.0$ & 3.63 & $1.02^{* * *}$ & $<0.001$ & 32 & 30 \\
\hline$>4.5$ & 4.00 & $1.39^{* * *}$ & 0.001 & 5 & 5 \\
\hline
\end{tabular}

Notes: *** $\mathrm{p}<0.01$.

Source: Own elaboration. 
Table 9 shows that medium-sized manufacturing companies are already quite competitive (3.46) with an above-average level of market orientation ( $>3$ ). Their competitiveness increases quite slowly at the next two levels of market orientation (by 0.09 and by 0.08 ) to then increase considerably (by 0.37) at the ultra-high level (>4.5).

Table 10. Market orientation and competitiveness of large manufacturing companies

\begin{tabular}{|c|c|c|c|c|c|}
\hline $\begin{array}{c}\text { Market } \\
\text { orientation }\end{array}$ & $\begin{array}{c}\text { Competi- } \\
\text { tiveness } \\
\text { Index }\end{array}$ & Difference & $\begin{array}{c}\text { p-value of } \\
\text { Mann-Whitney } \\
\text { U-test }\end{array}$ & $\begin{array}{c}\text { No. of } \\
\text { companies }\end{array}$ & $\begin{array}{c}\text { Share } \\
(\%)\end{array}$ \\
\hline$\leq 3.0$ & 3.30 & - & - & 5 & 15 \\
\hline$>3.0$ & 3.36 & 0.06 & 0.851 & 29 & 85 \\
\hline$>3.5$ & 3.61 & 0.31 & 0.638 & 18 & 53 \\
\hline$>4.0$ & 3.81 & 0.51 & 0.518 & 9 & 26 \\
\hline$>4.5$ & 4.25 & 0.95 & 0.381 & 2 & 6 \\
\hline
\end{tabular}

Source: Own elaboration.

The results presented in Table 10 reveal that large companies differ from the previously analysed smaller firms operating in the manufacturing industry. However, it must be noted that the differences are not statistically significant, which can result from the fact that it is the smallest group among those analysed in this article, containing only 34 firms.

Despite the fact that the observed differences are not statistically significant, some conclusions can be drawn from the data. First, it must be underlined that large manufacturing companies are, in general, very competitive. This is the only group in which even enterprises with an average or lower than average $(\leq 3)$ level of market orientation are more competitive than their closest competitors (3.30). Secondly, there is a very small difference (0.06) in competitiveness between companies with average or lower than average and higher than average market orientation. At the higher levels $(>3.5,>4,>4.5)$, however, competitiveness increases considerably - ultra-highly market-oriented companies are especially competitive (4.25).

\section{Conclusions}

The presented analyses give grounds for a number of conclusions and pieces of practical advice for manufacturing companies, among which the most important is the observation that the rising level of market orientation is practically always accompanied by an increase in competitiveness. The only doubt comes from 
large companies and some results for medium-high technology companies that were not statistically significant. No situation has been found in any of the distinguished group in which companies with a higher level of market orientation would be less competitive than those with a lower level of market orientation.

Another finding is that in the great majority of cases, manufacturing companies with an average or lower than average $(\leq 3)$ level of market orientation are less competitive than their closest competitors. The only exception are large companies.

The results also indicate that an above-average $(>3)$ level of market orientation is quite common among all kinds of manufacturing companies, unlike the highest, ultra-high ( $>4.5$ ) level. Such highly market-oriented companies constitute a competitive elite (4-10\% depending on company type, with the highest share among high technology companies). This shows that it is profitable to increase the level of market orientation as much as possible in order to create a strong competitive advantage. The conducted analyses also show that it is especially profitable for low, medium-low, and high technology companies, as it particularly increases their competitiveness.

An important limitation of the article is the fact that the data on which it is based was gathered quite a long time ago (in 2012 and at the beginning of 2013).

\section{Acknowledgements, sources of financing}

The paper and the study were financed by the National Science Centre, PRELUDIUM grant no. 2011/03/N/HS4/00429.

\section{References}

Armstrong G., Kotler P., 2011, Marketing: An introduction, Pearson, Upper Saddle River. Economist Intelligence Unit, 2011, The future of manufacturing: An Economist Intelligence Unit research programme sponsored by GE, http://files.gereports.com/wp-content/uploads/2011/ 10/Economist-intelligence-unit-manufacturingreport10.18.2011-copy.pdf [access: 12.08.2016].

Farrell M.A., Oczkowski E., 1997, An analysis of the MKTOR and MARKOR measures of market orientation: An Australian perspective, Marketing Bulletin, no. 8.

Fonfara K., 2007, Typologia zachowań przedsiębiorstw w procesie internacjonalizacji, Marketing i Rynek, no. 12 .

Fonfara K., 2014, Marketing partnerski na rynku przedsiębiorstw, Polskie Wydawnictwo Ekonomiczne, Warszawa.

Gaur S.S., Vasudevan H., Gaur A.S., 2011, Market orientation and manufacturing performance of Indian SMEs: Moderating role of form resources and environmental factors, European Journal of Marketing, no. 7/8.

Google Scholar, [n.d.], search phrase 'market orientation', https://scholar.google.pl/scholar?q $=\% 22$ market + orientation $\% 22 \&$ btnG $=\& \mathrm{hl}=$ pl\&as_sdt $=0 \% 2$ C5 [access: 09.08.2016]. 
Harris L.C., 2001, Market orientation and performance: Objective and subjective empirical evidence from UK companies, Journal of Management Studies, no. 1.

Hatzichronoglou T., 1997, Revision of the high technology sector and product classification, OECD Science, Technology and Industry Working Papers, 1997/02, http://dx.doi.org/10.1787/ 134337307632 [access: 26.03.2012].

Hooley G., Cox T., Fahy J., Shipley D., Beracs J., Fonfara K., Snoj B., 2000, Market orientation in the transition economies of Central Europe, Journal of Business Research, no. 50.

Jovane F., Yoshikawa H., Alting L., Boër C.R., Westkamper E., Williams D., Tseng M., Seliger G., Paci A.M., 2008, The incoming global and technological and industrial revolution towards competitive sustainable manufacturing, Manufacturing Technology, no. 57.

Kaźmierczyk J., 2011, Technologiczne $i$ społeczno-ekonomiczne determinanty zatrudnienia w sektorze bankowym w Polsce, CeDeWu, Warszawa.

Kohli A.K., Jaworski B.J., 1990, Market orientation: The construct, research propositions, and managerial implications, Journal of Marketing, no. 54.

Kohli A.K., Jaworski B.J., Kumar A., 1993, MARKOR: A measure of market orientation, Journal of Marketing Research, no. 30.

Loch C.H., Chick S., Huchzermeier A., 2007, Can European manufacturing companies compete? Industrial competitiveness, employment and growth in Europe, European Management Journal, no. 4.

Narver J.C., Slater S.F., 1990, The effect of a market orientation on business profitability, Journal of Marketing, no. 4.

Niestrój R., 2003, Istota i znaczenie marketingu, [in:] Podstawy marketingu, red. J. Altkorn, Instytut Marketingu, Kraków.

Noble C.H., Sinha R.K., Kumar A., 2002, Market orientation and alternative strategic orientations: A longitudinal assessment of performance implications, Journal of Marketing, no. 66.

Pazio N.M., 2007, Podstawy marketingu, Oficyna Wydawnicza Politechniki Warszawskiej, Warszawa.

Pelham A.M., 2000, Market orientation and other potential influences on performance in small and medium-sized manufacturing firms, Journal of Small Business Management, no. 1.

Pelham A.M., Wilson D.T., 1996, A longitudinal study of the impact of market structure, firm structure, strategy, and market orientation culture on dimensions of small-firm performance, Journal of the Academy of Marketing Science, no. 1.

Shapiro B.P., 1988, What the hell is 'market oriented'?, Harvard Business Review, no. 66.

Soniewicki M., 2015, The company's international competitive advantage: The role of knowledge, Difin, Warsaw.

Tajeddini K., Trueman M., Larsen G., 2006, Examining the effect of market orientation on innovativeness, Journal of Marketing Management, no. 5-6.

Wrenn B., 1997, The market orientation construct: Measurement and scaling issues, Journal of Marketing Theory and Practice, no. 3.

M. Soniewicki (-) marcin.soniewicki@ue.poznan.pl

Uniwersytet Ekonomiczny w Poznaniu, al. Niepodległości 10, 61-875 Poznań, Polska 